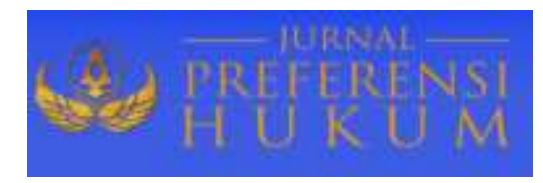

Jurnal Preferensi Hukum | ISSN: 2746-5039

Vol. 2, No. 2 - Juli 2021, Hal.337-342| Available online at

https://www.ejournal.warmadewa.ac.id/index.php/juprehum

DOI: https://doi.org/10.22225/jph.2.2.3331.337-342

\title{
TINJAUAN YURIDIS TERHADAP PENGGUNAAN JASA PIHAK KETIGA (DEBT COLLECTOR) DALAM MENAGIH KREDIT BERMASALAH PADA PT ADIRA DINAMIKA MULTIFINANCE TBK
}

\author{
Kasirinus Jee Lua, Anak Agung Sagung Laksmi Dewi, Ni Made Puspasutari Ujianti \\ Fakultas Hukum, Universitas Warmadewa, Denpasar-Bali, Indonesia \\ asryeka2017@gmail.com, laksmiidewi29@gmail.com, puspasutariujianti@gmail.com
}

\begin{abstract}
Abstrak
Penggunaan jasa pihak ketiga oleh perusahaan pembiayaan PT.Adira Dinamika Multifinance melalui perusahaan jasa pihak ketiga (debt couecton untuk melakukan fungsi penagihan terhadap konsumen atau debitur yang sulit ditagih dengan dinyatakan melakukan wanprestasi. Pengaturan penggunaan jasa pihak ketiga oleh perusahaan pembiayaan, diatur dalam POJK Nomor 35/POJK.05/2018 tentang Penyelenggaraan Usaha Perusahaan Pembiayaan, dimana perusahaan pembiayaan bisa melakukan kerjasama kepada pihak lain (jasa pihak ketiga) bertujuan untuk menagih kredit bermasalah., akibat yang ditimbulkan dari peristiwa kerjasama antara jasa pihak ketiga dengan perusahaan pembiayaan untuk menagih kredit bermasalah bahwa perusahaan pembiayaan bertanggung jawab penuh terhadap kerjasama yang dilakukan apabila ada perbuatan yang melanggar hukum sesuai dengan dalam POJK Nomor 35/POJK.05/2018. Namun jika perusahaan pembiayaan sudah melakukan prosedur yang ditetapkan dan jasa pihak ketiga tetap melakukan perbuatan melawan hukum maka pertanggungjawaban dibebankan kepada jasa pihak ketiga dalam rangka menagih kredit bermasalah. Pada penelitian ini menggunakan jenis penelitian hukum normatif. Teknik pengumpulan bahan hukum pada penelitian ini, yaitu dengan mengumpulkan dari studi kepustakaan dengan menggunakan teknik dokumenter/pencatatan yang diperoleh berkaitan dengan bahan hukum primer, sekunder, dan tersier.
\end{abstract}

Kata Kunci: Jasa Pihak Ketiga, Kredit, Penggunaan.

\begin{abstract}
The use of third party services by financing company PT Adira Dinamika Multifinance through a third party Service Company (debt couecton to perform a collection function for consumers or debtors who are difficult to collect by being declared in default. Regulations for the use of third party services by financing companies are regulated in POJK No. /POJK.05/2018 concerning the Implementation of Business Financing Companies, where financing companies can collaborate with other parties (third party services) with the aim of collecting nonperforming loans., The consequences of collaboration between third party services and financing companies to collect non-performing loans that the finance company is fully responsible for the cooperation carried out if there is an act that violates the law in accordance with POJK Number 35 / POJK.05 / 2018. However, if the financing company has carried out the prescribed procedure and the third party service continues to commit acts against the law, then the liability will be borne by the third party's services in order to collect non-performing loans. This research uses normative legal research. The technique of collecting legal materials in this study is to collect from literature studies using documentary / recording techniques obtained related to primary, secondary, and tertiary legal materials.
\end{abstract}

Keywords: Third Party Services, Credit, Usage.

\section{PENDAHULUAN}

Indonesia merupakan negara hukum. Sebagaimana tercantum dalam Pasal 1 Ayat (3) Undang-undang Dasar Negara Republik Indonesia Tahun 1945 (yang selanjutnya disebut UUD 1945) (Maksum, 2015). Memajukan kesejahteraan umum bagi seluruh rakyat Indonesia yang adil dan makmur, dengan tidak membeda-bedakan persona setiap warga negara termaktub dalam Undang-Undang-undang Dasar Negara Republik Indonesia Tahun 1945 (UUD 1945) yang merupakan tujuan negara. Dalam rangka itu pembangunan nasional yang diejawantahkan pada bidang perekonomian adalah upaya imanen pemerintah bersama warga negara mencapai tujuan tersebut. Posisi sentral perekonomian dibangun sebagian besar atas dasar kebutuhan pribadi yang mengoptimalkan pembelanjaan barang komersil baik itu berupa barang maupun jasa di masyarakat. Dengan begitu semakin banyaknya kebutuhan masyarakat akan barang dan jasa dalam pemenuhan kebutuhannya diperlukan suatu sistem pembiayaan 
yang fleksibel. Pembiayaan ini muncul guna membantu biaya pembelian barang dan jasa baik itu berupa tunai maupun secara tidak tunai atau kredit.

Selain bank adanya lembaga non bank yang melakukan kegiatan pembiayaan yakni perusahaan pembiayaan menambah geliat ekonomi yang mempunyai peran cukup penting sebagai sumber pengelolaan dana pengembangan pembangunan. Perusahaan pembiayaan ini salah satu alternatif bagi masyarakat untuk memenuhi konsumerismenya dalam membeli sesuatu berupa kredit. Peraturan Otoritas Jasa Keuangan Nomor 35/POJK.05/2018 pada Pasal 2 dan Pasal 3 menyebutkan bahwa perusahan pembiayaan tidak menarik dana secara langsung dari masyarakat dan dapat melakukan kegiatan dengan beberapa cara dalam rangka melakukan penyediaan dana atau barang modal.

Salah satu perusahaan pembiayaan yang sudah lama bergerak di pembiayaan konsumen yang bersifat konsumtif adalah PT Adira Dinamika Multifinance Tbk. Pada saat konsumen akan melakukan pembelian sesuatu apakah itu kendaraan bermotor misalnya dengan cara kredit, maka perusahaan pembiayaan akan menganalisa dan membuat perjanjian dengan kesepakatan antara perusahaan pembiayaan dan konsumen. Kemudian terjadilah hak dan kewajiban dari masing-masing pihak, dimana perusahaan pembiayaan selaku kreditur mempunyai hak dan kewajibannya dan konsumen selaku debitur mempunyai hak dan kewajibannya. Maka proses kredit berjalan dan debitur melakukan angsuran yang telah ditetapkan selama jangka waktu tertentu dan besaran biaya angsuran yang telah disepakati. Pada saat berjalannya proses kredit masing-masing pihak harus patuh terhadap isi perjanjian yang telah disepakati bersama.

Timbul masalah ketika adanya wanprestasi yang dilakukan oleh debitur, dalam hal ini keterlambatan pembayaran angsuran, dengan kelalaian dalam melaksanakan kewajibannya sehingga mengakibatkan kredit macet atau kredit bermasalah. Tentu saja perusahaan pembiayaan akan melakukan penagihan, dengan cara sesuai dengan standar operasional perusahaan pembiayaan tersebut. Manakala terjadinya kesulitan dalam hal penagihan dikarenakan pihak konsumen tidak mau membayar atau menyerahkan jaminan tentu menjadi kesulitan tersendiri bagi pihak perusahaan pembiayaan. Dimana, perihal penagihan merupakan hak yang dipunyai oleh perusahaan pembiayaan terhadap konsumen/debitur yang telah gagal bayar atau melakukan wanprestasi karena tidak membayar angsuran atau kredit yang telah diperjanjikan.

Beberapa penelitian meneliti hal yang serupa dengan tujuan berbeda misalnya beberapa penelitian yang dilakukan oleh Nur Rima Cessio Magistri, Nyoman Serikat Putra Jaya berjudul "Tinjauan Yuridis Terhadap Perlindungan Hukum Korban Tindak Pidana Penusukan dalam Peradilan Pidana". Chant S. R. Ponglabba berjudul "Tinjauan Yuridis Penyertaan dalam tindak Pidana Menurut Kuhp". Cliff Edward Fransiscus Liono, Christine Tooy, Suriyono Suwikrono dalam penelitiannya berjudul "Tinjauan Yuridis Terhadap Penarikan Barang Jaminan Fidusia Secara Paksa Oleh Leasing Melalui Debt Collector Yang Ditinjau Berdasarkan Undang- Undang Nomor 42 Tahun 1999 Tentang Jaminan Fidusia".

Tatkala itu terjadi, perusahaan pembiayaan akan melakukan kerjasama dengan debtcollector(agen penagih) dimana berperan sebagai jasa pihak ketiga atau pihak lain, yang berarti bukan karyawan dari perusahaan pembiayaan, namun pihak luar yang diberi kuasa oleh perusahaan pembiayaan untuk bekerja sebagai penagih dan menangani konsumen/nasabah yang mengalami kredit bermasalah. Penyelesaian penagihan kredit bermasalah oleh debt collector terhadap konsumen pada pelaksanaannyabisa menimbulkan konflik baru antara debtcollector dengan konsumen, dimana debt collector bisa berbuat tindakan yang sewenang-wenang kepada konsumen ataupun sebaliknya dan perlu dicermati sebelumnya bahwa adanya perjanjian antara perusahaan pembiayaan dengan konsumen pada perjanjian pembiayaan yang telah disepakati.

\section{METODE PENELITIAN}

Pada penelitian ini menggunakan jenis penelitian hukum normatif. Normatif. Menurut H. Ishaq mendefinisikan penelitian hukum normatif pada hakikatnya mengkaji hukum yang dikonsepkan sebagai norma atau kaidah yang berlaku dalam masyarakat dan menjadi acuan perilaku setiap orang. Sedangkan menurut (Soerjono Soekanto dan Sri Mamuji, 2010: 13-14) Penelitian normatif atau disebut juga penelitian hukum kepustakaan adalah penelitian hukum yang dilakukan dengan cara meneliti bahan pustaka atau bahan sekunder belaka. Dengan menggunakan sumber bahan hukum yang meliputi bahan hukum primer, bahan hukum sekunder, dan bahan hukum tersier. Bahan hukum primer meliputi perundang-undangan, putusan-putusan hakim. Bahan hukum sekunder merupakan bahan yang 
diperoleh dari kepustakaan atau literatur yang berupa buku-buku, laporan penelitian, jurnal ilmiah, karya ilmiah di bidang hukum. Bahan hukum tersier merupakan bahan petunjuk maupun penjelasan atas bahan primer dan sekunder yang berupa kamus hukum, kamus umum, website, dan ensiklopedia. Teknik pengumpulan bahan hukum pada penelitian ini, yaitu dengan mengumpulkan dari studi kepustakaan dengan menggunakan teknik dokumenter/pencatatan yang diperoleh berkaitan dengan bahan hukum primer, sekunder, dan tersier. Sedangkan, bahan penelitian yang diperoleh dari bahan hukum primer, sekunder, dan tersier akan diolah dengan analisis kualitatif yakni bekerja dengan bahan, mengorganisasikan bahan, mensistematiskan dengan memberikan deskripsi yang digambarkan dengan kata-kata atau kalimat-kalimat secara sistematis untuk memperoleh kesimpulan secara sistematis dan umum.

\section{HASIL DAN PEMBAHASAN}

\section{Pengaturan Hukum terhadap Jasa Pihak Ketiga Perusahaan pembiayaan menurut Peraturan Otoritas Jasa Keuangan Nomor}

35/POJK.05/2018 tentang Penyelenggaraan Usaha Perusahaan Pembiayaan disebutkan badan usaha yang melakukan kegiatan pembiayaan barang dan/atau jasa. Pada peraturan tersebut disebutkan juga kegiatan perusahaan pembiayaan meliputi pembiayaan investasi, pembiayaan modal kerja, pembiayaan multiguna, dan/atau kegiatan usaha pembiayaan lain berdasarkan persetujuan Otoritas Jasa Keuangan. Dengan begitu berdasarkan pengertian tersebut unsur perusahaan pembiayaan terdiri dari:

1. Badan usaha

2. Kegiatan pembiayaan

3. Penyedia dana

4. Barang konsumsi dan produkti.

Pengertian kredit menurut Undang-undang 10 Tahun 1988 tentang Perubahan atas UndangUndang Nomor 7 Tahun 1992 tentang Perbankan yaitu penyediaan uang atau tagihan yang dapat dipersamakan dengan itu, berdasarkan persetujuan atau kesepakatan pinjam meminjam antara bank dengan pihak lain yang mewajibkan pihak peminjam melunasi utangnya setelah angka waktu dengan pemberian bunga. Sedangkan pengertian pembiayaan adalah penyedia uang atau tagihan yang dapat dipersamakan dengan itu, berdasarkan persetujuan atau kesepakatan antara bank dengan pihak lain yang mewajibkan pihak yang dibiayai untuk mengembalikan uang atau tagihan tersebut setelah jangka waktu tertentu. Dalam arti luas kredit diartikan sebagai kepercayaan (Kasmir, 2015 85).

Atas dasar kepercayaan itulah yang menjadi alasan seseorang mempunyai hak atas sesuatu terhadap orang lain yang merupakan dasar dari suatu perikatan. Perikatan inilah yang menjadi dasar antara para pihak dalam kesepakatan sewa menyewa, pinjam meminjam, prestasi, kepercayaan, dan adanya jangka waktu tertentu serta timbal balik yang berhubungan dengan suatu objek benda.

Didalam kredit adanya suatu perjanjian yang melahirkan perikatan, dalam hal ini antara pihak perusahaan pembiayaan dan konsumen. Perjanjian merupakan persetujuan yang bersumber dari kehendak dua pihak, sehingga orang terikat pada perjanjian karena kehendaknya sendiri, sedangkan pada undang-undang terlepas dari kehendaknya (Luh Nila Winarni, 2016:103). Ketentuan pada Pasal 1338 Ayat (1) Kitab Undang-Undang Hukum Perdata menyebutkan semua perjanjian yang dibuat secara sah berlaku sebagai undang-undang bagi mereka yang membuatnya.

Penggunaan kredit konsumen merupakan salah satu yang memiliki resiko tinggi, sehingga dalam pelaksanaannya bisa menimbulkan dalam pelunasan yang jika diteruskan akan menjadi masalah serius yakni kredit macet. Di Dalam perjanjian jika salah satu pihak tidak melakukan prestasi maka dikatakan wanprestasi yakni jika tidak melakukan apa yang diperjanjikan. Wanprestasi adalah kenyataan sebaliknya dari prestasi, Dalam hal ini, jika dalam prestasi, isi dari perjanjian dijalankan/dipenuhi oleh para pihak, maka dalam wanprestasi tidak menjalankan/memenuhi isi perjanjian yang bersangkutan (Munir Fuady, 2014 207).

Penekanan wanprestasi ketika konsumen (debitur) yakni ketika tidak mampu membayar cicilan atau tertunda pembayarannya maka akan dilakukan penagihan oleh perusahaan pembiayaan dalam hal ini PT Adira Dinamika Multifinance Tbk sesuai dengan haknya. Perusahaan pembiayaan akan melakukan tindakan penagihan dengan memperhatikan peraturan yang ada baik itu melalui standar operasional yang berlaku di internal maupun sesuai dengan peraturan perundang- undangan yang ada.

Akan tetapi jika cara ini tidak berhasil dikarenakan adanya kesulitan dalam penagihan maka perusahaan pembiayaan akan bekerjasama dengan jasa pihak ketiga atau pihak lain. Jasa adalah setiap 
tindakan atau kegiatan yang dapat ditawarkan oleh suatu pihak kepada pihak lain, yang pada dasarnya tidak berwujud dan tidak mengakibatkan kepemilikan apa pun. Produksinya dapat dikaitkan atau tidak dikaitkan pada satu produk fisik (Suharto Abdul Majid, 2011 33). Dapat dikatakan bahwa jasa pihak ketiga ini merupakan adanya suatu pihak lain untuk melakukan sesuatu atau diberdayakan oleh pihak yang sedang mempunyai hubungan perjanjian mengenai sesuatu hal dan dengan diiringi suatu perjanjian lainnya.

Penggunaan jasa pihak ketiga bukan merupakan orang internal atau karyawan dari perusahaan pembiayaan namun diberikan tugas yang berfungsi sebagai agen penagihan, sehingga menghubungkan antara kreditur (perusahaan pembiayaan) dan debitur (konsumen). Dapat dicermati jasa pihak ketiga mempunyai kewenangan untuk menagih kepada konsumen melalui surat kuasa yang berasal dari perusahaan pembiayaan selaku pihak yang menyewanya.

Keberadaan jasa pihak ketiga dalam menyelesaikan mengenai penagihan hutang-piutang pada perusahaan pembiayaan terdapat Peraturan Otoritas Jasa Keuangan Nomor 35/POJK.05/2018 tentang Penyelenggaraan Usaha Perusahaan Pembiayaan, tepatnya Pasal 48. Terlihat bahwa pihak lain yang dimaksud adalah pihak jasa ketiga atau jasa penagih (debt collector'). Ketentuan tersebut hadir sebagai payung hukum untuk menggunakan pihak ketiga dalam rangka fungsi penagihan kepada debitur, Dimana debt colledorharuslah dinaungi oleh pihak yang berbadan hukum debt collection, memiliki izin dari instansi yang berwenang, serta mempunyai sumber daya manusia yang telah disertifikasi kompetensi dibidang penagihan. Dengan demikian hal ini harus dipenuhi guna adanya payung hukum penggunaan jasa pihak ketiga oleh perusahaan pembiayaan PT Adira Dinamika Multifinance Tok. Hubungan antara PT Adira Dinamika Multifinance dengan perusahaan jasa pihak ketiga ini merupakan hubungan kerjasama yang dituangkan dalam suatu perjanjian sehingga pihak ketiga (debt collector) ini mendapatkan kuasa dari perusahaan pembiayaan untuk melaksanakan penagihan dan eksekusi agunan kepada konsumen.

Lebih lanjut mengenai penggunaan jasa pihak ketiga dalam Pasal 49 POJK 35/2018, adanya suatu rujukan internal yang dibuat oleh perusahaan pembiayaan di dalam mengeksekusi agunan maupun di dalam penagihan kredit bermasalah, artinya prosedur yang dilakukan oleh PT Adira Multifinance melalui pihak ketiga harus sesuai dengan yang diamanatkan oleh peraturan perundang-undangan yang berlaku. Kemudian pada Pasal 50 POJK 35/2018 mengenai eksekusi agunan, dimana debitur haruslah terbukti melakukan wanprestasi dan telah diberikan surat peringatan sesuai dengan ketentuan serta debitur patut diberikan penjelasan mengenai jumlah pokok terutang, bunga yang terutang, denda yang terutang, biaya terkait eksekusi agunan, bunga yang terutang, biaya terkait eksekusi agunan, dan mekanisme penjualan agunan dalam hal debitur tidak menyelesaikan kewajibannya. Alhasil, jasa pihak ketiga (debtcolledor) dapat bertanggung jawab langsung atas hal yang dilakukannya di lapangan kepada perusahaan pembiayaan yang nantinya juga akan diberikan pertanggungjawaban kepada Otoritas Jasa Keuangan.

\section{Akibat Hukum Penggunaan lasa Pihak Ketiga Dalam Penagihan Kredit}

Adanya kerjasama perusahaan pembiayaan dengan jasa pihak ketiga untuk menagih kredit bermasalah melalui hubungan perjanjian. Mencermati hal itu, di dalam perjanjian perdata antara perusahaan pembiayaan PT Adira Dinamika Multifinance Tbk dengan perusahaan jasa pihak ketiga dimana memuat hal-hal yang diperbolehkan dan yang tidak diperbolehkan yang tentu saja disepakati oleh masing-masing pihak. Perjanjian khusus yang tertulis ini disertai dengan surat kuasa dengan beberapa waktu tertentu yang bisa diperpanjang sesuai kebutuhan, dengan ini menand akan pemberian kuasa kepada jasa pihak ketiga sebagaimana hak dan kewajibannya. Sebagaimana sesuai ketentuan dari Pasal 1792 KUHP perdata disebutkan.

Pemberian kuasa ialah persetujuan yang berisikan pemberian kekuasaan kepada orang lain yang menerimanya untuk melaksana kan sesuatu atas nama orang yang memberikan kuasa.

Dapat dikatakan surat kuasa ini merupakan pelimpahan wewenang dari perusahan pembiayaan kepada jasa pihak ketiga dalam pelaksanaan penagihan hutang atau kredit. Kuasa ini nantinya yang akan diteruskan kepada petugas di lapangan (debt collector) untuk melakukan fungsi penagihan terhadap konsumen yang mengalami kredit macetjbermasalah untuk dipakai sebagaimana mestinya.

Tanggung Jawab kewajiban untuk penagihan kredit konsumen terhadap perusahaan pembiayaan tetaplah merupakan dibebankan kepada perusahaan pembiayaan. Namun hal ini dikuasakan kepada jasa pihak ketiga untuk melaksanakan tanggung jawab tersebut. Ketentuan 
Peraturan Otoritas Jasa Keuangan Nomor 35/POJK.05/2018 menjadi dasar perusahaan pembiayaan dalam menggunakan jasa pihak ketiga untuk fungsi penagihan. Dengan begitu adanya hubungan hukum antara perusahaan pembiayaan dengan jasa pihak ketiga menghasilkan konsekuensi tertentu atau akibat hukum tertentu antar kedua belah pihak.

Akibat hukum merupakan hasil dari adanya peristiwa hukum. Akibat hukum adalah suatu akibat akibat hukum adalah suatu akibat yang ditimbulkan oleh adanya suatu hubungan hukum. Suatu hubungan hukum memberikan hak dan kewajiban yang telah ditentukan oleh undang-undang, sehingga kalau dilanggar akan berakibat, bahwa orang yang melanggar itu dapat dituntut dimuka pengadilan (Soedjono Dirdjosisworo, 2016 132). Pada perjanjian khusus penggunaan jasa pihak ketiga bertindak sebagai pihak lain yang dalam kewajibannya menjalankan tugas penagihan, dimana jasa pihak ketiga perlu eksistensi untuk membuktikan kepada konsumen bahwa memang menjalankan proses penagihan dikarenakan sepenuhnya konsumen memerlukan identitas untuk kepentingan konsumen. Proses penagihan sendiri telah ada didalam ketentuan POJK Nomor 35/POJK.05/2018, dimana penagihan merupakan upaya dan aktivitas untuk rnemperoleh dari hak dan kewajiban oleh perusahaan pembiayaan atas angsuran yang yang dibayarkan konsumen yang mana termasuk ke dalamnya melakukan eksekusi agunan bilamana konsumen wanprestasi. Oleh karenanya secara hukum kerjasama perusahaan pembiayaan dan pihak jasa ketiga (debt collector"; bisa dilakukan untuk fungsi penagihan. Pada POJK Nomor 35/POJK.05/2018 tepatnya Pasal 48 Ayat (4) disebutkan perusahaan pembiayaan wajib bertanggung jawab penuh atas segala dampak yang ditimbulkan dari kerja sama dengan pihak lain. Akibat yang timbul yang telah diatur dalam Pasal 48 tersebut maka perusahaan pembiayaan wajib bertanggung jawab secarahukum atas kelalaian atau kesalahanyang dilakukan oleh jasa pihak ketiga.

Dengan demikian bilamana dalam menjalankan tugas yang diberikan kepada jasa pihak ketiga (debt couecton dalam hal eksekusi, namun berujung kepada perbuatan yang membuat kerusakan atau kerugian, maka perusahaan pembiayaan harus bertanggung jawab. Namun apabila dalam menjalankan tugas yang diberikan kepada jasa pihak ketiga (debt collector"; telah melanggar atau mengindahkan tata peraturan yang telah ditentukan baik itu menurut perundang- undangan maupun perjanjian kerjasama dengan perusahaan pembiayaan, maka jasa pihak ketiga hanya bisa yang disalahkan.

Dalam hal penagihan konsumen menyerahkan jaminannya pada saat dilakukan penagihan oleh jasa pihak ketiga maka sesuai dengan Undang-Undang Nomor 42 Tahun 1999 tentang Jaminan Fidusia pemberi fidusia wajib menyerahkan benda yang menjadi objek jaminan fidusia dalam rangka pelaksanaan eksekusi jaminan fidusia yang merupakan hak atas perusahaan pembiayaan. Kemudian jika ada konsumen yang tidak terima dengan eksekusi yang dilakukan dengan melakukan perlawanan apalagi sampai dengan melakukan tindakan kriminal maka dapat dipertanggungjawabkan perbuatannya sesuai dengan ketentuan hukum positif yang berlaku di Indonesia, dalam hal ini Kitab Undang-Undang Hukum Pidana (KUHP).

\section{SIMPULAN DAN SARAN}

\section{Simpulan}

Berdasarkan penjelasan dari penelitian ini, maka dapat disimpulkan beberapa poin yaitu:

1. Pengaturan hukum mengenai penggunaan jasa pihak ketiga (debt collector) oleh perusahaan pembiayaan sebagai fungsi penagihan terhadap kredit bermasalah debitur (nasabah) di Indonesia secara normatif diatur dalam ketentuan Peraturan Otoritas Jasa Keuangan Nomor 35/POJK.05/2018 tentang Penyelenggaraan Perusahaan Pembiayaan Pasal 48. Berdasarkan uraian dapat dilihat meskipun kerjasama penggunaan jasa pihak ketiga terdapat pada aturan POJK tersebut, namun di dalam Pasal 48 disebutkan kerjasama dengan pihak lain untuk melakukan proses penagihan kepada debitur, bukan menggunakan jasa pihak ketiga dalam penagihan sehingga memiliki penafsiran yang rancu atau multitafsir dalam penerapannya.

2. Akibat hukum yang ditimbulkan dalam kerjasama menggunakan jasa pihak ketiga oleh pihak perusahaan pembiayaan untuk proses penagihan kredit bermasalah dengan menggunakan prinsip pedoman yang telah diberikan untuk melakukan eksekusi di lapangan, menjadi tanggung jawab perusahaan pembiayaan sepenuhnya jika di dalam prosesnya terdapat unsur-unsur tindakan melawan hukum ataupun sengketa hukum yang timbul. Namun jika perusahaan pembiayaan sudah melakukan sesuai dengan prosedur yang telah ditetapkan dengan koridor yang ada, dan jasa pihak ketiga (debt collector') tidak melakukan penagihan sebagaimana yang sudah diatur dan disepakati tersebut, maka tanggung jawab hukum akan berada di perusahaan yang menaungi debt collector tersebut. 


\section{Saran}

Berdasarkan hasil penelitian dan analisis data, peneliti memberikan beberapa saran, sebagai berikut:

1. Bagi pihak perusahaan jasa pihak ketiga agar dapat lebih melakukan pembinaan kepada personilnya agar dapat memperhatikan aturan perundang-undangan yang berlaku dan menerapkan prinsip kehati-hatian mengingat ada kepentingan nasabah/konsumen/debitur sehingga tidak terjadinya kerugian yang terlalu besar.

2. Bagi pihak pemerintah dalam menentukan kebijakan terhadap penggunaan jasa pihak ketiga agar lebih rinci dan detail sehingga tidak menimbulkan penafsiran yang beragam pada pelaksanaannya.

\section{DAFTAR PUSTAKA}

Dirdjosisworo, S. (2016). Pengantar Ilmu Hukum (Cet.18). PT Rajagrafindo Persada. Jakarta. Fuady, M. (2014). Konsep Hukum Perdata. PT Rajagrafindo Persada. Jakarta.

H, I. (2017). Metode Penelitian Hukum \& Penulisan Skripsi, Tesis dan Disertasi. Alfabeta. Bandung.

Kasmir. (2015). Bank dan Lembaga KeuanganLainnya. PT. Rajagrafindo Persada. Jakarta. Majid, S. A. (2011). CustomerService dalam BisnisJasa Transportasi. PT. Grafindo Persada. Jakarta.

Magistri, N. R. C. (2020). Tinjauan Yuridis Terhadap Perlindungan Hukum Korban Tindak Pidana Penusukan Dalam Peradilan Pidana. Pembangunan Hukum Indonesia, Vol.2 (1).

M, M. (2015). Penerapan Hukum Jaminan Fidusia dalam kontrak Pembiayaan Syari"ah. Vol. 3(1).

Ponglabba, C. S. R. (2017). Tinjauan Yuridis Penyertaan dalam Tindak Pidana Menurut Kuhp. LEX CRIMEN, Vol. 6(6).

Soekanto, S., \& Mamuji, S. (2010). Penelitian Hukum Normatif Suatu Tinjauan Singkat. PT Rajagrafindo Persada. Jakarta.

Winarni, L. N. (2016). PrinsipItikad Baik Dalam Pembuatan dan Pelaksanaan Kontrak. Udayana University Press. Denpasar. 